\title{
EFFICACY OF CERTAIN INSECTICIDES AGAINST RAT FLEA (XENOPSYLLA CHEOPIS) AMONG RODENT SPECIES IN CAIRO GOVERNORATE, EGYPT

\author{
By
} \\ MOHAMED ISMAIL SOLIMAN, AZZA S. ABD EL- HALIM AND MICHEAL WILLIAM MIKHAIL \\ Research Institute of Medical Entomology, Ministry of Health, Dokki, Giza, Egypt
}

\begin{abstract}
The efficacy of malathion, chlorpyrifos and deltamethrine to oriental rat flea, Xenopsylla cheopis associated different rodent species was carried out in Cairo Governorates. The results indicated that the $\mathrm{Lc}_{50}$ values were $1.972,1.023$ and $0.185 \%$ for Malathion, Chlorpyrifos and Deltamethrine, respectively. The values of $\mathrm{Lc}_{90}$ were $4.452,2.269 \& 0.456 \%$ for the three insecticides respectively. Data also indicated that deltamethrine was effective on fleas than malathion and chlorpyrifos. The slope function was $3.625,3.70 \& 3.267$, respectively.
\end{abstract}

Key Words: Rodent, Fleas, Malathion, Chlorpyrifos, Deltamethrine, Insecticides.

\section{Introduction}

Fleas are bloodsucking parasites of birds and mammals in the order Siphonaptera. Adult fleas are flattened from side to side and are wingless. The larvae are pale and caterpillar-like. Fleas can travel rapidly by jumping, using their legs and spring-like mechanism the body. They are capable of spectacular leaps, covering distances up to one hundred times their body length. Only adult fleas feed on blood, which they obtain with their piercing/sucking mouthparts. Fleas larvae feed on organic debris in bedding or in sleeping areas, and in dust and lint debris in carpeting. However, they are commonest in areas where animals sleep. Female fleas lay eggs in these areas. The eggs take about two weeks to hatch, depending on temperature. Larval fleas look very different from the adults, having long body hairs, and appearing caterpillaror worm-like, without eyes or legs. Larvae spin a skin cocoon before transforming into adults. The complete life cycle from egg to egg takes 3-4 weeks depending on food availability and temperature; the warmer temperature the faster the fleas life cycle. Adult fleas are capable of living long period, particularly at cold temperatures, without feeding. In a few instances, fleas are known to live one or two months without a blood meal. Some fleas are responsible to transmit for a number of medical and veterinary problems. The most severe infectious disease spread by fleas is the plague, caused by $Y$. pestis (Stenseth et $a l, 2008)$. Fleas are Known as vectors of murine typhus (endemic typhus fever, $R i$ ckettsia typhi), and played a role in the rural epidemic typhus fever ( $R$. prowuzeki) in the USA (WHO, 1989). The flea-borne spotted fever caused by Rickettsia felis emerged and could be found in many countries worldwide (Perez-osorio et al, 2008). The cat fleas have also been proven to harbor and sometimes transmit Bartonella henselae, the causative agent of the cat-scratch disease (Chomel et al, 2006; Billeter et al, 2008). Additionally, fleas are hosting helminthes, Dipylidium caninum and Hymenolepis diminuta, respectively parasites of camivores and rats (Duchemin et al, 2006). In tropical areas, Tangiasis caused by $T$. penetrasis a human disease directly linked to the parasitism of humans by fleas (Reiss, 1966). However, to many of general population, the insidious attacks by fleas on people and domestic animals causing irritation, blood loss, and severe discomfort are equally important as disease threat. Xenopsylla cheopis is common in many tropical and warm temperate envi- 
ronments around the world, although it probably arose in north-eastern Africa. This flea is the primary vector of $Y$. pestis the agent of plague (Bitam et al, 2006), and is involved in transmission of murine (endemic) typhus (Brouqui and Raoult, 2006) and parasitic helminthes (Bordes et $a l, 2007)$. Bartonella sp have also been detected (Reeves et al, 2007). In fact, Xenopsylla cheopis is widely disseminated on various species of rodents in different parts of the world. In Egypt records were given by Abdou and Smaan (1962), Hoogstraal (1956), Arafa et al. (1973); Rifaat et al. (1969); Morsy et al. (1982) and Mahmoud et al. (2008).

The present work was planned to investigate the efficacy of Malathion, Chlorpyrifos and Deltamethrine chemical insecticides against the rat flea, Xenopsylla cheopis associated with the different rodent species trapped from Cairo Governorate.

\section{Materials and Methods}

The method described by Rifaat et al. (1969) for capturing and transporting of rodents to research laboratory was adopted throughout the present study. The study was done from June 2014 to November 2014. Wire box traps were baited and distributed in selected residential houses before sunset and collected next morning before sunrise. Distributed traps will be collected next morning and enclosed in sepa- rate white bag to avoid escape fleas and transported to laboratory (Elsheikha et al, 2009). In laboratory animals were anaesthetized with diethyl ether and fleas were collected on white sheet by using a stiff hard brush (WHO, 1970). Fleas collected were exposed to 4 concentrations of each insecticide (Malathion, Chorpyrifos and Deltamethrin). Papers $5 \times 1.5 \mathrm{~cm}$, tapered at one end impregnated with each concentration for each insecticide used was kindly provided by the WHO. A test paper and a control paper impregnated with oil alone were inserted into each of the test tubes. Into each tube, 10 fleas were transferred by means of the aspirator unit. Each tube was closed by fine-mesh gauze and the exposure period began. The tubes are placed vertically in rack under one of the halves of the kit box so that the fleas were kept in darkness during the exposure period. Each concentration was replicated 4 times with concurrent control. At the end of 60 minutes exposure period, the tubes were transferred to clean tubes containing clean non-impregnated paper. After 24 hours, the fleas examined and mortality counts were calculated. The method described by Finney (1952) and the logarithmic-probability was used to evaluate the relationship between concentrations and mortality. The slope (b) function ratio was also calculated.

\section{Results}

The results are shown in tables (1\&2).

Table 1: Response of fleas to different concentrations of insecticides in Cairo Governorate.

\begin{tabular}{|c|c|c|c|c|c|}
\hline Insecticide & Concentration $\%$ & No. of fleas & Died & Alive & Mortality \% \\
\hline \multirow{4}{*}{ Malathion } & 1.0 & 40 & 7 & 33 & 17.5 \\
\cline { 2 - 6 } & 2.0 & 40 & 19 & 21 & 47.5 \\
\cline { 2 - 6 } & 3.0 & 40 & 26 & 14 & 65 \\
\hline \multirow{4}{*}{ Chlorpyrifos } & 4.0 & 40 & 38 & 2 & 95 \\
\cline { 2 - 6 } & 0.5 & 40 & 5 & 35 & 12.5 \\
\hline \multirow{4}{*}{$\begin{array}{c}\text { Delta- } \\
\text { methrin }\end{array}$} & 1.0 & 40 & 19 & 21 & 47.5 \\
\cline { 2 - 6 } & 1.5 & 40 & 30 & 10 & 75 \\
\cline { 2 - 6 } & 2.0 & 40 & 34 & 6 & 85 \\
\hline
\end{tabular}


Table 2: Insecticides efficacy against fleas in Cairo Governorate.

\begin{tabular}{|c|c|c|c|c|c|c|c|c|}
\hline \multirow[b]{2}{*}{ Insecticides } & \multicolumn{2}{|c|}{$\begin{array}{c}\text { Lc values \& } \\
\text { Lower and upper }\end{array}$} & \multirow{2}{*}{$\begin{array}{l}\mathrm{Lc}_{50} / \\
\mathrm{Lc}^{90}\end{array}$} & \multirow{2}{*}{$\begin{array}{l}\text { Slope } \\
\text { (b) }\end{array}$} & \multicolumn{2}{|c|}{$\begin{array}{c}\text { Toxicity in-dex } \\
\text { based on }\end{array}$} & \multicolumn{2}{|c|}{$\begin{array}{c}\text { Folds } \\
\text { based on }\end{array}$} \\
\hline & $\mathrm{Lc}_{50}$ & Lc 90 & & & $\mathrm{Lc}_{50}$ & $\mathrm{Lc}^{90}$ & $\mathrm{Lc}_{50}$ & $\mathrm{Lc}^{90}$ \\
\hline Malathion & $\begin{array}{c}1.145 \& 1.972 \\
\text { and } \\
2.85\end{array}$ & $\begin{array}{c}3.020 \& 4.452 \\
\text { and } \\
21.38\end{array}$ & 0.44 & $\begin{array}{c}3.625 \\
\pm \\
0.5\end{array}$ & 9.38 & 10.24 & 1 & 1 \\
\hline Chlorpyrifos & $\begin{array}{c}0.877 \& 1.023 \\
\text { and } \\
1.174\end{array}$ & $\begin{array}{c}1.174 \& 2.269 \\
\text { and } \\
3.139\end{array}$ & 0.45 & $\begin{array}{c}3.70 \\
\pm \\
0.5\end{array}$ & 18.08 & 20.09 & 1.92 & 1.96 \\
\hline $\begin{array}{l}\text { Delta- } \\
\text { methrine }\end{array}$ & $\begin{array}{c}0.154 \& 0.185 \\
\text { and } \\
0.215\end{array}$ & $\begin{array}{c}0.365 \& 0.456 \\
\text { and } \\
0.667\end{array}$ & 0.40 & $\begin{array}{c}3.267 \\
\pm \\
0.5\end{array}$ & 100 & 100 & 10.65 & 9.76 \\
\hline
\end{tabular}

\section{Discussion}

The insecticidal efficacy of Malathion, Chlorpyrifos and Deltamethrine was evaluated against oriental rat flea ( $X$. cheopis). The lethal concentration (Lc) 50 \& 90 of population percent were obtained from the established regression log concentrateresponse lines. The results indicated that Deltamethrine was more effective to fleas than Chlorpyrifos and Malathion. The lethal concentration values $\left(\mathrm{Lc}_{50}\right)$ were, $1.972,1.023$ and $0.185 \%$ for Malathion, Chlorpyrifos and Deltamethrine, respectively. The same finding and trend were obtained with $\left(\mathrm{Lc}_{90}\right)$ showed the values of 4.452, 2.269 and $0.456 \%$ for Malathion, Chlorpyrifos and Deltamethrine, respectively. Data of the slope of the established regression lines indicated that the investigated population of fleas showed almost the same degree of response homogeneity toward Malathion, Chlorpyrifos and Deltamethrine. The slope values were 3.625, 3.70 and 3.267 for Malathion, Chlorpyrifos and Deltamethrine, respectively. Taking the values of $1 c_{50}$ and $l c_{90}$ of Deltamethrine as a base line for comparison (Sun, 1950), the relative frequencies of Malathion and Chlorpyrifos reached $9.38 \& 18.08$ based on $\mathrm{Lc}_{50}$ and $10.24 \& 20.09$ based on $\mathrm{Lc}_{90}$, respectively. Also taking the values of $\mathrm{Lc}_{50}$ and $\mathrm{Lc}_{90}$ of Malathion as a base line for comparison the relative frequencies of Chlorpyrifos and Deltamethrine reached $1.92 \& 10.65$ based on $\mathrm{Lc}_{50}$ and $1.96 \&$ 9.76 based on Lc $_{90}$, respectively. The density of flea infesting domestic rodents in
Egypt was reported by several investigators. Soliman et al. (2010) reported that the commonest flea species that attacked rodents at Menoufia Governorate were $X$. cheopis, L. segnis and C. canis. Mahmoud et al. (2008) found that the commonest fleas species attacking rodents at Suez, Menoufia, Giza, Damietta and Beni-Suef Governorates, were $X$. cheopis, $C$. felis, $L$. segnis and $P$. irretans. Shoukry et al. (1986) in North Sinai Governorate identified two species of flea; $X$. cheois and $C$. segnis. The same author et al. (1987) reported that fleas were the predominate ectoparasites in Ismailia Governorate. These fleas were $X$. cheopis (682), Echidnophaga gallinacea (667) and Ctenocephlides segnis (41). Morsy et al. (1988) in Alexandria City reported that fleas represented the main ecto-parasite infesting commensal rodents. These fleas in a descending order of abundance were $X$. cheopis, $L$. senis, $C$. felis and P. irritans. Zeese et al. (1990) in Sharkia Governorate identified five species of fleas from domestic rodent species, which were $X$. cheopis L. segnis, c. felis C. canis and P. irritans. Khalid et al. (1992) showed that $X$. cheopis the main ectoparasite on the rodent hosts over the year, the highky infested rodent was $R$. norvegicus. Morsy et al. (1986) in Suez Governorate studied the fleas that attacked the different rodent species (Mus musculus, Rattus rattus, Rattus norvegicus, Acomys cahirinus and Sekeetamys culurus), and identified in a descending order of abundance; Xenopsylla cheopis, Pulex irritans, 
Ctenocephalides felis, C. segnis and Echidnophaga gallinacean.

Regarding insecticides against fleas, Soliman and Mikhail (2011) reported that Bendicarb was more effective than Diazinon and Pirimiphos-methyl against fleas were collected from domestic rodents at Dakahlia Governorate. The $\mathrm{Lc}_{50}$ values were $0.389,1.039 \& 2.056 \%$ for Bendicarb, Diazinon and Pirimiphosmethyl, respectively. Abroad, Ratovonjato (1998) showed that $X$. cheopis for urban areas in Madagascar were resistance to DDT and pyrethroids (Deltamethrin, Lambdacyhalothr- in, Permethrin), but were susceptible to $1 \%$ Bendiocarb and Pirimiphosmethyl. Rato- vonjato et al. (1998) carried out field study for the efficacy of different insecticides against $X$. cheopis over the years 1997-98 in urban areas in Antananarivo, Madagascar; found that Deltamethrin was inefficient in causing a decrease of the flea index. Conversely, immediately after the treatment with Bendiocarb and Pirimiphosmethyl, the flea index decreased significantly. Arvind Kumar et al. (2007) tested the toxicity of Malathion on two species of rat fleas namely $X$. cheopis and $X$. astia in Distt Baghpat of western Uttar Pradesh. The mortality of $82.15 \%$ was recorded in $X$. cheopis and $85.71 \%$ in $X$. astia after exposed for one hour. Males of both species showed more sensitivity to insecticide than females. Shyamal et al. (2008) reported the development of resistance in rat fleas to DDT at $4.0 \%$, Malathion at 5.0\%, Deltamethrin at $0.05 \%$ and tolerance to Permethrin at $0.75 \%$ in all the four blocks of Nilgiris hill district. The development of resistance was attributed to the extensive use of insecticides in tea plantations and agricultural sectors where the domestic/ peri-domestic rodents lived their natural habitats and intermingle with each other. Yi et al. (2008) studied the resistance rates of $X$. cheopis at $\mathrm{Lc}_{50}$ values of Malathion (0.0165), Propoxur (0.117), Dichorovos (0.0202) Pe-rmethrin (0.0002), Deltame- thrin (0.0038) and Fendona (0.0087) for the different insecticides, respectively, that $4.78,16.42,2.08,1.70,1.66 \& 2.94$ times. They concluded the large amount and constant of flea insecticides might lead to the marked resistance.

Burgess (2010) reported that synthetic pyrethroids were commonly used especially against lice infestation as they cause less ecological problems and are available as sprays, vaporizing mats, mosquito coils or in combination with physical means such as bed-nets Singh and Mann (2013) stated that fleabites may produce psychological distress and that treatment consisted of eradication of flea infestation in the source pet-animal. They added that Permethrin acts by its agonist action at voltage-gated sodium channels (VGSC) in nervous systems of insects. Selective point mutations in $\alpha$-subunit gene of VGSC result in nerve insensitivity, resulting in resistance known as knockdown resistance (kdr). DantasTorres et al. (2013) used different commercial products with insecticidal, repellent or both properties for dogs. They found that a combination of Imidacloprid $10 \%$ and Flumethrin $4.5 \%$ has proven effective to prevent tick and flea infestations in dogs under field conditions and the infection by some vector-borne pathogens they transmit. Ratovonjato et al. (2000) studied the susceptibility of $X$. cheopis collected from different rural areas in Madagascar (Ambodislarivo, mandoto, Analaroa and Besoa) to Deltamethrin (0.025\%), Cyfluthrin (0.15\%), DDT (4\%), Propoxur $(1 \%)$ and Bendiocarb (0.1\%). X. cheopis collected from Mandoto and Analaroa showed to tolerance to Deltamethrin and Cyfluthrin, but was susceptible to Propoxur and Bendiocarb. Fleas collected from Besoa were resistant to DDT, tolerant to Deltamethrin and Cyfluthrin, but susceptible to Propoxur and Bendiocarb.

In Egypt, Mikhail et al. (2011) in a field survey study reported that the flea index at Ismailia and Matrouh Governorates found 
the highest indices ( $8.93 \& 7.68)$, while ElFayoum and North Sinai Governorates showed the lowest ones (1.09\& 1.68). Dakhalia showed moderate flea index of 4.52. The highest number was recorded on $R$. norvegicus in places easy to dig barrows and suitable medium for fleas breeding. The lowest number was recorded on Mus musculus and Acomys cahirinus. The oriental rat flea, Xenopsylla cheopis was the highest frequency distribution for all domestic rodent species, while, the stick-tight flea, Echidnophaga gallinacea was the lowest which recorded at Ismailia and Dakahlia only. El-Bahnasawy et al. (2012) reported that the outbreak of plague at the Libyan Egyptian borders may occur due to the high density of rodents and their fleas in many Egyptian Governorates should be embarked a control program to rodents and fleas. The toxicity of insecticides to fleas was reported by several investigators.

\section{Conclusion}

The outcome results showed that Cairo Governorates were distinguished by the presence of high population density of rodents which more heavily infested with fleas. Their intimate association with man is of great potential danger as disseminators of serious pathogens. In addition, the outbreaks of plague at State of Libya near the Egyptian border and the high density of fleas parasitic on rodents at most Governorates, that should be embarked a control program to rodents and their fleas.

\section{References}

Abdon, AH, Samaan M, 1962: Egyptian Rodents and their Public Health Importance. J. Arab. Vet. Med. Assoc. 22, 4:403-31.

Arafa, MS, Mahdi, AH, Khalil, MS, 1973: Seasonal observation on the Cairo spiny mouse, Acomys chahirinus and its fleas in Egypt. J. Egypt. Publ. Hlth. Assoc. XLVII:60-9.

Arvid-Kumar, Singh, PP, Kumar, K, 2007: Susceptibility status of Xenopsylla cheopis and Xenopsylla astia to malathion. Uttar Pradesh J. Zool. 1:123-7.

Billeter, SA, Levy, MG, Chomel, BB, Breit- schwerdt, EB, 2008: Vector transmission of Bratonella species with emphasis on the potential for tick transmission. Med. Vet. Entomol. 22:1-15.

Bitam, I, Baziz, B, Rolain, JM, Belkaid, M, Raoult, D, 2006: Zoonotic focus of plague, Algeria. Emerg. Infect. Dis.12:1925-77.

Bordes, F, Blumstein, DT, Morand, S, 2007: Rodent sociality and parasite diversity. Biol. Lett. 3: 692-4.

Brougui, P, Raoult, D, 2006: Arthropodborne diseases in homeless. Ann. N. Y. Acad. Sci. 1078:223-35.

Burgess, IF, 2010: Do nit removal formulations and other treatments loosen head louse eggs and nits from hair? Med. Vet. Entomol. 24:55-61.

Chomel, BB, Boulouis, HJ, Maruama, S, Breitschwerdt, EB, 2006: Bartonella spp. In: Pets and effect on human health. Emerg. Infect.12:389-94.

Dantas-Torres, F, Capelli, G, Giannelli, A, Ramos, RA, Lia, RP, et al, 2013: Efficacy of an imidacloprid/flumethrin collar against fleas, ticks and tick-borne pathogens in dogs. Parasit. Vectors 6, 1:245.

Duchemin, JB, Fournier, PE, Parola, P, 2006: Les puces et les maladies transmises a l'homme. Med. Trop. 66:21-9.

El-Bahnasawy, MM, Ahmed, GMS, AbdelFattah, MA, Gaber, WAF, Morsy, TA, 2012: Is plague a problem in the Egyptians returning back from Libya? J. Egypt. Soc. Parasitol. 42, 2:329-48.

Elsheikha, HM, Clayton, SJ, Morsy, TA, Yon, LK, 2009: Parasitic zoonoses at the rodent-captive primate-human health interface. J. Egypt. Soc. Parasitol. 39, 2:447-60.

Finney, DJ, 1952: Probit Analysis: A Statistical Treatment of the Sigmoid Response Curve. Cambridge University Press.

Hoogstraal, H, 1956: The flea (Siphonaptera) of Egypt: Host-parasite relationship of rodents of the families Spalacidae, Muridae, Gliridae, Dipodidae and Hystricidae. J. Egypt. Pub. Hlth. Assoc. 39: 1-35.

Khalid, ML, Morsy, TA, El-Sheeawy, SFA, Farrag, AMK, Mostafa, AA, 1992: Studies on flea fauna in El-Fayoum Governorate, Egypt. J. Egypt. Soc. Parasitol. 22, 3:783-99.

Mahmoud, KA, Metwally, AM, Mangoud, AH, Mohamed, AS, 2008: Survey of commensal rodents and their fleas in different 
Egyptian Agroecosystems. J. Agric. Res. 6: 2105-116.

Mikhail, MW, Soliman, MI, Morsy, TA, 2011: The current status of fleas according to environmental changes in some governorates in Egypt. J. Egypt. Soc. Parasitol. 41, 1:199212

Morsy, TA, Abou El-Ela, RG, El Gozamy, BMR, 1988: The commensal rodents and their fauna in Alexandria city, Egypt. J. Egypt. Soc. Parasitol. 18, 1:11-28.

Morsy, TA, Fayad, MF, Abou-Shady, AKA, Yousef, NSH, 1986: Ectoparasites of rodents in Suez Governorates with special reference to fleas. J. Egypt. Soc. Parasitol. 16, 2:457-67.

Morsy, TA, Michael, SA, Bassili, WR, Salah, MSM, 1982: Studies of rodents and their zoonotic parasites, perticulary leishmania, in Ismailia Governorate. Egypt. J. Egypt. Soc. Parasitol. 12, 2:565-85.

Perez-Osorio, CF, Velazquez, JE, Arias Leon, JJ, Zavala-Castro, JE, 2008: Rickettsia felis as emergent global threat for humans. Emerg. Infect. Dis.14:1019-23.

Ratovonjato, J, 1998: Susceptibility of Xenopsylla cheois to insecticides in urban areas in Madagascar.1'Institut Pasteur de Madagascar. 64, 1/2:25-8

Ratovonjato, J, Duchemin, J B, Duplantier, JM, chanteau, S, 2000: Xenopsylla cheopis (Siphonaptera: Xenopsylline), Fleas in rural households in the Hautes Terres region in Madagascar: Level of susceptibility to DDT, to pyrethroids and to carbamates after 50 years of chemical control. Arch. Inst. Past. Madagascar 66, 1/2:9-12.

Ratovonjato, J, Duchemin, JB, Duplantier, JB, Duplantez, JM, Laventure, S, et al, 1998: The assessment of the susceptibility of Malagasy pest fleas to insecticides in urban areas. Arch. Inst. Pasteur Madagascar 64, 1/2: 29-33.

Reeves, WK, Rogers, TE, Durden, LA, Dasch, GA, 2007: Association of Bartonella with the fleas (Siphonaptera) of rodents and bats using molecular techniques. J. Vector Ecol. 32:118-22.

Reiss, F, 1966: Tungiasis in New York City. Arch. Dermatol., 93:404-07.

Rifaat, MN, Mohammed, AM, Shawarby, AA, Arafa, MS, 1969: Incidence and distribution of domestic \& commensal rodents in UA R. J. Egypt. Pub. Hlth. Assoc. 44, 2:127- 46.
Shoukry, A, Morsy, TA, Abu Hashish, TA, El Kady GA, 1986: Seasonal activities of tow commensal rats and flea index in North Sinai Governorate, Egypt. J. Egypt. Soc. Parasitol. 16, 2:385-93.

Shoukry, A. Morsy, TA, Farahat, AA, 1987: Arthropod-ectoparasites for rodents trapped in Ismailia Governorate, Egypt. J. Egypt. Soc. Parasitol. 17, 2:525-37.

Shyamal, B, Ravi Kumar, R, Sohan, L, Balakrishnan, N, Veena, M, et al, 2008: Present susceptibility status of rat flea Xenopsylla cheopis (Siphonaptera: Pulicidae), vector of plague against organochlorine, organophosphate and synthetic pyrethroids 1- The Nilgiris District, Tamil Nadu, India. J. Commun. Dis. 40, $1: 41-5$.

Singh, S, Mann, BK, 2013: Insect bite reactions. Indian J. Dermatol. Venereol. Leprol. 79, 2:151-64

Soliman, MI, Abd El-Halim, AS, Mikhail, MW, 2010: Rodent borne diseases and their fleas in Menoufia Governorate, Egypt. J. Egypt. Soc. Parasitol. 40, 1:107-17.

Soliman,MI, Mikhail, MW, 2011: Field studies on dominant rodents and the efficacy of certain insecticides to their fleas in Dakahlia Governorate, Egypt and their fleas in Menoufia Governorate, Egypt. J. Egypt. Soc. Parasitol. 41, 2:315-26.

Stenseth, NC, Atshabar, BB, Begon, BB, BeImain, SR, Bertherat, E, et al, 2008: Plague: Past, present and future. PLoS. Med.5:e3.

Sun, YP, 1950: Toxicity index anal improved method of comparing the relative toxicity of insecticides. J. Econ. Entomol. 43:45-53.

WHO, 1970: Instruction resistance and vector control: Tech. Rep. Ser. 443, Wld. Hlth. Org., Geneva.

WHO, 1989: geographical distribution of arthropod-borne diseases and their principal vector. Report No. WHO/WBC/89.967

Yi, JR, Guang, LQ, Lifeng, L, Ming, LR, 2008: Study on the resistance and control strategy of Xenopsylla cheopis to six insecticides in Guangdong plague natural focus, Chinese. Chinese J. Vector Boil. Cont.19, 4:31719.

Zeese, W, Khalaf, SA, Abou-El-Ela, RG, Morsy, TA, 1990: Rodents and their ectoparasites in Sharkia Governorate, Egypt. J. Egypt. Soc. Parasitol. 20, 2:827-35. 